\title{
Receptor Regulation in Taste: Can Diet Influence How We Perceive Foods?
}

\author{
Ashkan A. Shahbandi ${ }^{1,+}{ }^{\mathbb{D}}$, Ezen Choo ${ }^{2,+}$ and Robin Dando ${ }^{3, *} \mathbb{D}$ \\ 1 Biological Sciences, Cornell University, Ithaca, NY 14853, USA; aas328@cornell.edu \\ 2 Pharmacology, Cornell University, Ithaca, NY 14853, USA; ec649@cornell.edu \\ 3 Department of Food Science, Cornell University, 247 Stocking Hall, Ithaca, NY 14853, USA \\ * Correspondence: robin.dando@cornell.edu; Tel.: +1-(607)-254-3319; Fax: +1-(607)-254-4868 \\ + Authors contributed equally to the work.
}

Received: 26 September 2018; Accepted: 10 October 2018; Published: 14 October 2018

\begin{abstract}
Taste buds are the dedicated sensory end organs of taste, comprising a complex and evolving profile of signaling elements. The sensation and ultimate perception of taste depends on the expression of a diverse array of receptors and channels that sense their respective tastes. Receptor regulation is a recognized and well-studied phenomenon in many systems, observed in opioid addiction, insulin resistance and caffeine tolerance. Results from human sensory studies suggest that receptor sensitivity or expression level may decrease after chronic exposure to respective tastants through diet. We review data supporting the theory that taste receptors may become downregulated with exposure to a specific tastant, along with presenting data from a small pilot study, showing the impact of long-term tastant exposure on taste receptor expression in mice. Mice treated with monosodium salt monohydrate (MSG), saccharin and $\mathrm{NaCl}$ (typically appetitive tastes) all displayed a significant decrease in mRNA expression for respective umami, sweet and salty receptors/sensory channels. Reduced sensitivity to appetitive tastes may promote overconsumption of foods high in such stimuli.
\end{abstract}

Keywords: taste; diet; dietary exposure; taste receptor; taste modulation; flavor; dietary preference

\section{Taste and Taste Buds}

Taste is a sensory gatekeeping mechanism, designed to test our foods before they are consumed, for positive (appetitive) and negative (aversive) qualities. Thus, we perceive sweet, umami and salty (at low levels) as pleasant, and sour and bitter as undesirable, with a growing argument for the perception of fat as a true basic taste [1]. In this role, taste buds are implicitly tied to obesity, due to their being at least partially responsible for determining the foods we choose to consume. In humans and mice, taste buds are comprised of three cell types based on their morphologic characteristics: Type I (glial-like cell), Type II (receptor cell), and Type III (presynaptic cell) taste cells. These structural differences result in a host of unique functions making the taste cell particularly responsive to explicit taste stimuli. While Type II cells have been well characterized, transduction mechanisms associated with Type I and Type III cells remain more ambiguous. Type I cells have been shown to produce ionic currents in response to salt stimuli, [2], with salty taste transduction thought to occur at least primarily through the epithelial sodium channel ENaC [3,4]. Type II cells utilize G-protein-coupled transduction in response to sweet, bitter or umami, though individual Type II cells are thought to express receptors for only one stimulus [5]. Sweet and umami receptors are heterodimers formed from Tas1R subunits [6,7]. Tas1R1 and Tas1R3 form the umami receptor, and Tas1R2 and Tas1R3 form the sweet receptor [8]. A single bitter-sensitive cell can express several monomeric Tas2Rs [9]. Type III cells are thought to be responsible for the perception of the sour [10], possibly involving the transient 
receptor potential (TRP) channel polycystic kidney disease 2-like 1 protein (PKD2L1) [11-13], although these channels may simply mark the cell, and not be involved in active transduction [14].

\section{Receptor Regulation}

Receptor regulation is a well-studied epigenetic phenomenon, whereby chronic exposure to a receptor agonist leads to diminished expression of its cogent receptor. Such a response confers some adaptive value to the cells, whereby it allows continued receptor function in an environment of varying agonist concentration, and may result in superior input-output coupling [15], and improve signaling dynamic range. This mechanism underlies cellular actuation of drug addiction and forms of so-called homologous desensitization, whereby a cell becomes less sensitive to a specific agonist, while remaining functional and responsive to others. While some studies detail rapid and quickly reversed internalization of receptors (i.e., [16]), we aim in this communication to discuss more long-lasting chronic downregulation of taste receptors analogous to that found in systemic conditions of elevated agonist concentration, along with the presenting of a short pilot study designed to test this theory in a group of mice exposed to specific tastants over a four-week period.

In cultured human lymphocytes, radioligand binding assays first revealed a lack of receptor sites after chronic insulin exposure [17], a putative mechanism for reduced receptors observed in insulin-resistant mice [18], leading to reduced insulin binding affinity [19]. Despite the number of receptors in insulin-resistant mice being starkly diminished, their individual function remained similar to a healthy mouse [20]. This process is blocked by using cycloheximide to inhibit protein synthesis [21]. Bar et al. [22] soon demonstrated an inverse relationship in obese humans between receptor concentration and plasma insulin levels, confirming this system of feedback. Similarly, a downregulation in glucocorticoid receptors after agonist exposure is evident when testing both in cell lines [23], and in human lymphocytes [24].

Leptin is a circulating protein hormone correlated with adipose cell mass and linked to satiation. Excess body fat leads to an elevated level of plasma leptin, reversible with weight loss, thus leptin resistance is commonly observed in the obese [25]. Both leptin receptor mRNA and protein were decreased in the appetite centers of the hypothalamus of rats administered exogenous leptin for four weeks [26]. Stimulation of $\beta$-adrenergic receptors caused a rapid decrease in the number of functional receptors present in the rat pineal gland [27]. This led to a dampened response when the surrounding norepinephrine concentration was high. Lefkowitz and colleagues demonstrated a decrease in functional receptors in frog erythrocytes desensitized to prostaglandin E1, leading to a drop in resultant adenylate cyclase [28].

Taste receptors are not confined to the oral cavity, but also perform similar chemosensory roles throughout the body. There are hints that such receptors may be influenced by their respective ligands. Depriving mice of food for $24 \mathrm{~h}$ leads to overexpression of Tas1R1 and Tas1R2 in the hypothalamus, but not the cortex [29]. Tas1R3 is expressed alongside Tas1R2 in sweet-sensing beta cells of the pancreatic islets. This expression is markedly decreased in fed mice when compared to fasted [30]. In adipose tissue of mice fed a low-carbohydrate diet, both Tas1R2 and Tas1R3, responsible for the detection of sweet, are upregulated [31]. Finally, a recent report details how obesity, originating from a high-fat diet, can cause downregulation of many signaling elements of taste, including Tas1R3, in the hypothalamus and brainstem of mice [32]. In addition, the authors reported that high levels of glucose resulted in a decrease in expression of Tas1R2 in in-vitro experiments with cultured hypothalamic neurons. Taken together, these data provide a compelling argument for the possibility that taste receptors may be regulated by an excess or scarcity of their cogent receptors. Despite salt and sour taste seemingly being transduced via ion channels, for consistency we will refer to the potential regulation of sensors for all five basic tastes from this point as "receptor" regulation. 


\section{Evidence for Receptor Regulation in the Perception of Taste}

Our sense of taste is influenced by genetic, physiologic and behavioral inputs. Taste buds turn over with a half-life of 8-24 days [32], leaving them in a constant state of development. This development may be influenced by the host's nutrition and/or physiology, which in turn is sensitive to dietary intake. As we use our taste buds to assess foods and decide whether to consume or reject, an intriguing question is, "what is the impact of diet on taste response?" If such receptor regulation occurs in taste, then a situation may occur whereby the constant consumption of a particular stimulus leads to an inability to perceive such stimuli, thus likely influencing our food selection. In this vein, patients prescribed a low-salt diet for five months to combat hypertension perceive the intensity of salt higher than if maintained on a regular diet [33], without changes in weight or urine volume. The authors of this study postulate that a "peripheral physiological adjustment" may be responsible for such observations. This could imply a change in receptor expression, as well as some form of long-term receptor adaptation, changes in innervation, changes in saliva content, etc. Intriguingly, dietary intake in sodium tablets did not elicit such an effect; the sodium must be perceived as taste in order for a perceptual deficiency to occur [34]. An inability to correctly identify salt concentrations was also linked to sodium consumption by Pangborn and Pecore [35].

Likewise, for sweet taste, in the second month on a low-sugar diet, panelists begin to perceive moderately sweet foods as being more sweet than those on a regular diet [36], with stronger effects still after longer treatment. Interestingly, blocking sweet taste perception promotes the consumption of more sweet foods, and thus presumably higher calorie stimuli [37]. Fat taste sensitivity may be upregulated by a diet low in fats, with a corresponding decrease in sensitivity for those on a high-fat diet [38], with some variation in this effect based on body mass index. The perception of umami taste similarly seems to be downregulated through long-term exposure [39]. Many studies examine bitter taste and diet, though genetic linkages make any causal interpretation more difficult (see reviews [40,41]). Such work seems scarce examining dietary treatments of highly sour or bitter foods.

Though research indicates that there may be an association between diet and perceived taste intensity in human sensory testing, research surveying an impact at the molecular level is relatively sparse. A recent study concerning the development of lipid preference linked short-term fat intake with the downregulation of candidate lipid-sensor receptors in mice, indicating that diet appears to influence the molecular development of taste buds [42]. Similarly, dietary consumption of fats has also been shown to reduce the expression of the candidate fat receptor CD36 in rat taste buds [43]. On a longer timeline, diet-induced obesity (via excess consumption of fats) decreases taste-induced functional responses in the excised taste buds of mice [44]. However, for the five conventionally accepted "basic" tastes, there remains little evidence of receptor regulation.

\section{Exposure to Appetitive but Not Aversive Taste Stimuli Decreases mRNA Expression of Cogent Receptors}

In order to test the central hypothesis of this paper, a brief pilot experiment was performed (for materials and methods, see Section 6). C57BL/6 male and female mice aged 12-16 weeks were assigned to one of five treatment groups, or a control group ( $n=3-4$ mice per group). Each treatment group was exposed to one of five basic prototypic taste stimuli $(0.05 \mathrm{mM}$ quinine, $30.0 \mathrm{mM}$ L-glutamic acid monosodium salt monohydrate (MSG), $90.0 \mathrm{mM}$ sodium chloride $(\mathrm{NaCl}), 2.0 \mathrm{mM}$ saccharin, and $20.0 \mathrm{mM}$ citric acid) in their drinking water ad libitum over a four-week period, with controls given unadulterated water. Mice were weighed at the beginning and end of the treatment period, and drinking solutions were also measured to confirm sufficient liquid consumption. After four weeks of exposure, taste buds were extracted from the circumvallate papillae (the highest density of taste buds on the tongue) and tested for mRNA expression level of cogent sensors via qRT-PCR.

There were no significant differences in weight between any of the treatment groups and the control group. A primary concern was dehydration due to lack of water consumption when presented 
with an aversive stimulus; however, no difference was found between weights before and after, or between mice who consumed an aversive versus appetitive solution (see Figure 1).

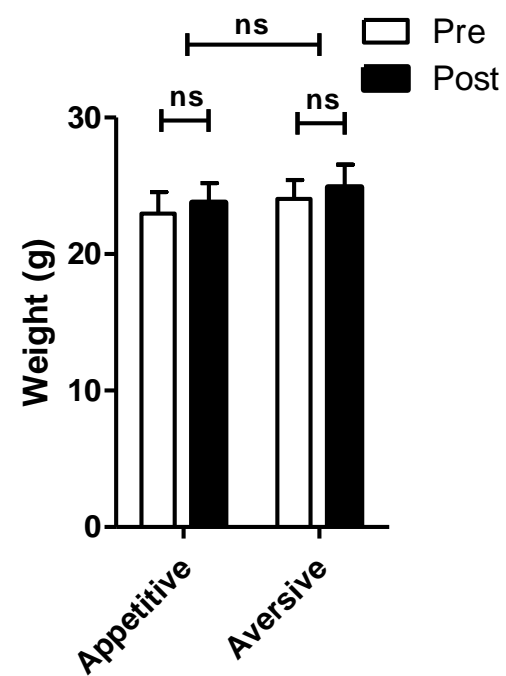

Figure 1. Mice weight throughout treatment. Weights prior to and following 4 weeks of tastant exposure were similar across taste modality (appetitive: salty- $\mathrm{NaCl}$; sweet-saccharin; umami-monosodium glutamate. Aversive: bitter—quinine $\mathrm{HCl}$; sour—citric acid. 2-way ANOVA, $p$-value for treatment = 0.591; aversive vs appetitive $=0.476$.).

Expression levels for the receptors and channels associated with detection of the five basic tastes were tested with qRT-PCR (Figure 2). The taste buds of mice exposed to MSG exhibited a decreased expression of mRNA for the umami taste receptor subunit Tas1R1 when compared to control mice exposed to only water. In addition, the taste buds of saccharin-exposed mice had downregulation of the sweet receptor taste subunit Tas1R1 mRNA compared to control mice. Finally, mice exposed to $\mathrm{NaCl}$ displayed decreased expression of mRNA for the putative salt-sensing channel ENaC compared to control mice. These data would agree with results from human sensory testing of the appetitive tastes for sweet, umami and salty taste, which become less sensitive with continued exposure.
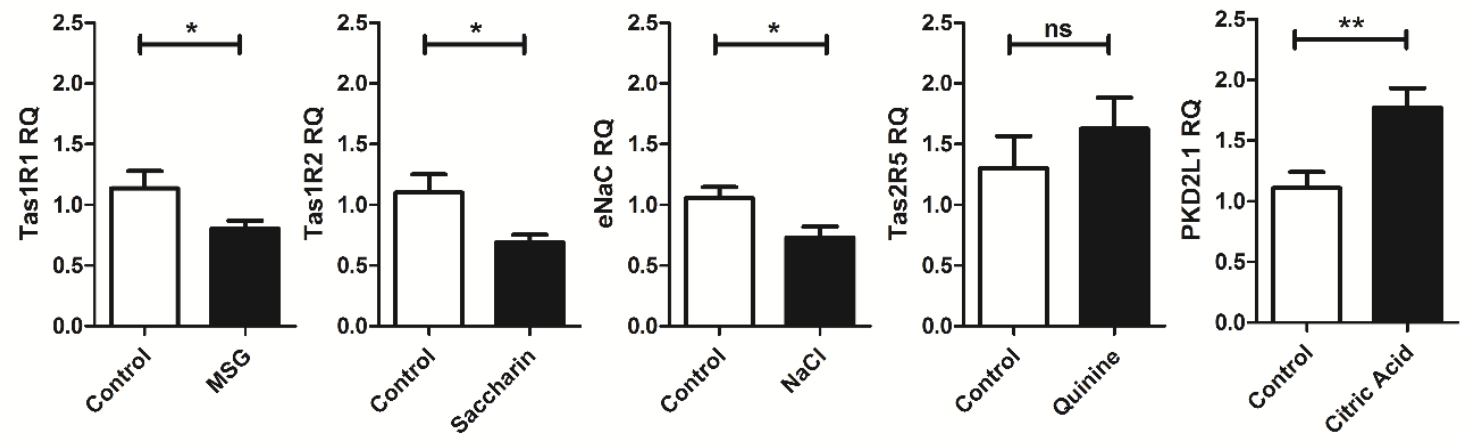

Appetitive tastes

Aversive tastes

Figure 2. Relative expression for the umami receptor (Tas1R1), sweet receptor (Tas1R2), epithelial sodium channel (ENaC) for salt, bitter receptor (Tas2R5), and polycystic kidney disease 2-like 1 protein (PKD2L1) for sour in mice treated with $30.0 \mathrm{mM}$ MSG, $2.0 \mathrm{mM}$ saccharin, $90.0 \mathrm{mM} \mathrm{NaCl}, 0.05 \mathrm{mM}$ quinine, and $20.0 \mathrm{mM}$ citric acid, respectively. Receptor mRNA expression was decreased after exposure to appetitive tastes, but not for aversive tastes. Expression was normalized to endogenous $\beta$-actin. Y-axis denotes relative expression (RQ) of each target of interest. Data shown as mean $\pm \mathrm{SEM}$, with results of ANOVA with post-hoc Tukey's test. Significance represented as ns (not significant, $p>0.05$ ); ${ }^{*}(p \leq 0.05) ;{ }^{* *}(p \leq 0.01)$. 
Such a trend was not observed in mice treated with prototypic sour and bitter stimuli. Interestingly, mRNA levels for the bitter receptor Tas2R5 did not change with long-term exposure to quinine (Figure 2). Further still, the expression for the candidate sour receptor PKD2L1 was increased with exposure to citric acid (see Figure 2). While salty taste may be perceived as aversive at high concentrations, treatment for a four-week period with such high concentrations was not conducive to our experimental design, due to the potential for dehydration of the animals.

\section{Implications for Chemosensory Perception and Food Choice}

Our findings indicate that long-term exposure to taste stimuli can alter the taste bud at a molecular level. Here we show that exposures to appetitive sweet, umami and salty tastes produce a taste-specific reduction in cognate receptors. This may lead to an inability to accurately judge the nutrient content of food, as appetitive tastes drive central reward. The relation of diet to sweet perception has been previously established in studies linking human obesity - a metabolic disease associated with long-term overconsumption-to decreased sensory perception of sweet taste [45]. A molecular basis for the phenomenon of decreased sweet perception in response to long-term overconsumption has yet to be established. Thus, the finding that long-term exposure to the artificial sweetener saccharin results in a decreased expression of Tas1R2 implicates taste development as a potential target for future obesity research.

The pilot study surveyed the molecular consequences associated with long-term tastant exposure to elaborate upon existing evidence of tastant-stimulated downregulation of key sensory receptors. The resulting alteration of receptor expression in response to stimulus overexposure is not novel in itself, and is in fact a molecular phenomenon commonly associated with overexposure in non-taste tissues to receptor agonists such as caffeine [46]. Downregulation of taste receptors in response to long-term tastant exposure was evident in the mice exposed to sweet, umami and salty stimuli, which the appetitive tastes comprise. In the case of the umami taste, mice provided long-term MSG treatment displayed decreased expression of Tas1R1, the proposed G-protein-coupled receptor primarily responsible for the perception of the umami taste [47]. Mice provided with long-term exposure to sodium chloride similarly displayed a decreased expression of the salty taste-associated sodium ion channel ENaC [4]. It should be noted that the concentrations of $\mathrm{NaCl}$ provided would not be sufficient to activate the aversive taste response linked recently to bitter-sensitive cells [48]. This may offer a molecular explanation for why dietary exposure to salts is linked to salt acceptance [49]. An interesting question remaining would be if chemosensory cells within the gastrointestinal tract are also undergoing such receptor expression on consumption of foods high in respective tastants.

Though any explanation for this observed trend remain speculative, the upregulation of sour receptor RNA expression could be the result of an adaptive molecular response in mice to be able to better perceive aversive compounds, and thus evolutionarily dangerous stimuli they are exposed to. Quinine was selected for long-term treatments due to its previous use as a broad stimulus of Tas2Rs [50] and its low potential for off-target effects that may have occurred with a more selective agonist cycloheximide [51], a protein translocation inhibitor which can cause DNA damage. Perceived bitterness from both caffeine [52] and 6-N-propylthiouracil [53] has been noted previously to correlate with bitter receptor mRNA expression. A seeming lack of change in Tas2R5 expression may thus be due to the use of a less selective agonist, however, the limitations of our study design made this difficult to discern. Our treatment would likely allow for taste cells to turn over more than once (see [32]), thus would allow for cells to be replaced with new taste cells, allowing for developmental changes routed in epigenetics. The development of a diverse arsenal of aversive taste receptors emerged as an evolutionary response to positive selection mediated by exposure to toxins, as the ability to perceive and avoid harmful substances confers fitness advantages [15]. Frequent exposure to aversive stimuli may serve as a selective force in treated mice to more readily express receptors conferring an ability to better perceive and avoid these hazardous substances. 


\section{Materials and Methods}

\subsection{Animals}

Data were collected from wild-type C57BL/6 male and female mice aged 12-16 weeks, representing fully aged mature mice. Mice were single housed in standard plastic cages with stainless steel grid lids, in a controlled facility, for the duration of the treatment period. Mice were allowed to eat and drink ad libitum. All interactions were in accordance with Cornell University's Institutional Animal Care and Use Committee (IACUC) regulations.

\subsection{Dietary Treatment}

Mice were assigned to either a treatment or control group ( $n=4$ mice per group). One mouse was ultimately removed from the saccharin group due to a health issue. Each group was exposed to one of five basic prototypic taste stimuli $(0.05 \mathrm{mM}$ quinine, $30.0 \mathrm{mM}$ L-glutamic acid monosodium salt monohydrate (MSG), $90.0 \mathrm{mM}$ sodium chloride $(\mathrm{NaCl}), 2.0 \mathrm{mM}$ saccharin, and $20.0 \mathrm{mM}$ citric acid) or water ad libitum over a four-week period. Mice were closely monitored to ensure there was no significant change in fluid intake or weight regulation. Tastant concentrations were chosen as around, or moderately lower than $\mathrm{EC}_{50}$ values based on published values from human or mouse studies [54-57]. Mice were weighed at the beginning and end of the treatment period, and drinking solutions were also measured to confirm sufficient liquid consumption.

\subsection{Taste Bud Isolation}

At the end of the 4-week treatment and upon euthanizing, mouse tongues were excised and immediately placed in Normal Tyrode's $(13.5 \mathrm{mM} \mathrm{NaCl}, 5.0 \mathrm{mM} \mathrm{KCl}, 2.0 \mathrm{mM} \mathrm{CaCl} 2,1.0 \mathrm{mM} \mathrm{MgCl}$, $3.5 \mathrm{mM} \mathrm{NaHCO} 3,10.0 \mathrm{mM}$ HEPES (4-(2-hydroxyethyl)-1-piperazineethanesulfonic acid), $10 \mathrm{mM}$ glucose, $10.0 \mathrm{mM}$ sodium pyruvate, $\mathrm{pH}: 7.4)$. Enzyme cocktail $(1.0 \mathrm{mg} / \mathrm{mL}$ collagenase type I, $0.25 \mathrm{mg} / \mathrm{mL}$ elastase, $0.5 \mathrm{mg} / \mathrm{mL}$ DNAse I, and $2.5 \mathrm{mg} / \mathrm{mL}$ dispase type II) was injected under the tongue epithelium surrounding the circumvallate papilla. Following a short incubation in $\mathrm{Ca}^{2+}$-free Normal Tyrode's, the epithelium was peeled away from the tongue. The epithelial layer was then secondarily incubated in enzyme cocktail for $2 \mathrm{~min}$ and $\mathrm{Ca}^{2+}$-free Normal Tyrode's for 5 min with rinses of Normal Tyrode's before and after each step. Taste buds were removed from the epithelium using a glass fire-polished micropipette. Taste buds and non-taste tissue samples were collected into lysis buffer for subsequent RNA extraction using Absolutely RNA nanoprep and microprep kit (Agilent Technologies, Santa Clara, CA, USA).

\section{4. $q R T-P C R$}

Total RNA was extracted from taste and non-taste tissue with added DNase1 step to remove genomic contamination [58] and then reverse-transcribed using cDNA Superscript (Quanta Biosciences, Gaithersburg, MD, USA). qRT-PCR was carried using PowerUp SYBR-green (Life Technologies, Carlsbad, CA, USA) on the QuantStudio 6 Flex Real-Time PCR System (Life Technologies, Carlsbad, CA, USA). Primer sequences are provided in Table A1.

\subsection{Data Analysis}

Statistical significance of obtained qRT-PCR relative expression data was determined via two-tailed $t$-test for comparison between two groups, and via ANOVA with post-hoc Tukey's HSD test for comparisons between more than two groups using JMP statistical software (SAS Institute, Cary, NC, USA). Plots illustrating obtained qRT-PCR relative expression data were generated in GraphPad Prism (GraphPad Software, La Jolla, CA, USA). 
Author Contributions: Conceptualization, A.A.S. and R.D.; formal analysis, A.A.S. and R.D.; investigation, A.A.S. and E.C.; writing—original draft preparation, A.A.S.; writing—review and editing, A.A.S., E.C., R.D.; visualization, R.D.; project administration, R.D.

Funding: Funding for the project was partially provided by the Cornell University Einhorn Discovery Grant awarded to A.A.S.

Conflicts of Interest: The authors declare no conflict of interest.

\section{Appendix}

Table A1. Forward and reverse primers for each gene of interest tested with qRT-PCR for RNA expression of taste and control genes.

\begin{tabular}{ccc}
\hline Gene & Direction & Sequence $^{\left(\mathbf{5}^{\prime} \text { to } \mathbf{3}^{\prime} \mathbf{)}\right.}$ \\
\hline B-actin & Forward & CACCCTGTGCTGC \\
& Reverse & GCACGATTTCCCT \\
PLC 32 & Forward & GAGCAAATCGCCA \\
& Reverse & CCTTGTCTGTGGT \\
Tas1R1 & Forward & GTGGAATGGACCTGAATGGAC \\
& Reverse & AGCAGCAGTGGTGGGAAC \\
Tas1R2 & Forward & AAGCATCGCCTCCTACTCC \\
& Reverse & GGCTGGCAACTCTTAGAACAC \\
Tas2R5 & Forward & GAATCATAGAAACAGGACCTCG \\
& Reverse & CTTTACAAAGGCTTGCTTTAGC \\
PKD2L1 & Forward & TGCGCCTGAGGAAAGAGCGG \\
& Reverse & AAGCGGCCGCTAGGACGGATTATACA \\
ENaC & Forward & GGCAGCCCACCGAGGAGGA \\
& Reverse & GCCACAGCACCGCCCAGAA \\
Gustducin & Forward & TGTGCCAAATGAACAAGACGTTCT \\
& Reverse & CTGATCTCTGGCCACCTACATCAA \\
TRPM5 & Forward & GTCTGGAATCACAGGCCAAC \\
& Reverse & GGTGATGTGCCCCAAAAACT \\
Protein Kinase C & Forward & TGAATCCTCAGTGGAATGAGT \\
& Reverse & GGTTGCTTTCTGTCTTCTGAA \\
\hline
\end{tabular}

\section{References}

1. Running, C.A.; Craig, B.A.; Mattes, R.D. Oleogustus: The unique taste of fat. Chem. Senses 2015, 40, 507-516. [CrossRef] [PubMed]

2. Vandenbeuch, A.; Clapp, T.R.; Kinnamon, S.C. Amiloride-sensitive channels in type I fungiform taste cells in mouse. BMC Neurosci. 2008, 9, 1. [CrossRef] [PubMed]

3. Heck, G.L.; Mierson, S.; DeSimone, J.A. Salt taste transduction occurs through an amiloride-sensitive sodium transport pathway. Science 1984, 223, 403-405. [CrossRef] [PubMed]

4. Chandrashekar, J.; Kuhn, C.; Oka, Y.; Yarmolinsky, D.A.; Hummler, E.; Ryba, N.J.; Zuker, C.S. The cells and peripheral representation of sodium taste in mice. Nature 2010, 464, 297-301. [CrossRef] [PubMed]

5. Tomchik, S.M.; Berg, S.; Kim, J.W.; Chaudhari, N.; Roper, S.D. Breadth of Tuning and Taste Coding in Mammalian Taste Buds. J. Neurosci. 2007, 27, 10840-10848. [CrossRef] [PubMed]

6. Nelson, G.; Hoon, M.A.; Chandrashekar, J.; Zhang, Y.; Ryba, N.J.; Zuker, C.S. Mammalian sweet taste receptors. Cell 2001, 106, 381-390. [CrossRef]

7. Di Pizio, A.; Levit, A.; Slutzki, M.; Behrens, M.; Karaman, R.; Niv, M.Y. Comparing Class A GPCRs to bitter taste receptors: Structural motifs, ligand interactions and agonist-to-antagonist ratios. Methods Cell Biol. 2016, 132, 401-427. [PubMed]

8. Zhao, G.Q.; Zhang, Y.; Hoon, M.A.; Chandrashekar, J.; Erlenbach, I.; Ryba, N.J.; Zuker, C.S. The receptors for mammalian sweet and umami taste. Cell 2003, 115, 255-266. [CrossRef]

9. Kuhn, C.; Meyerhof, W. Oligomerization of sweet and bitter taste receptors. Methods Cell Biol. 2013, 117, 229-242. [PubMed] 
10. Huang, Y.A.; Maruyama, Y.; Stimac, R.; Roper, S.D. Presynaptic (Type III) cells in mouse taste buds sense sour (acid) taste. J. Physiol. 2008, 586, 2903-2912. [CrossRef] [PubMed]

11. Ishimaru, Y.; Inada, H.; Kubota, M.; Zhuang, H.; Tominaga, M.; Matsunami, H. Transient receptor potential family members PKD1L3 and PKD2L1 form a candidate sour taste receptor. Proc. Natl. Acad. Sci. USA 2006, 103, 12569-12574. [CrossRef] [PubMed]

12. Huang, A.L.; Chen, X.; Hoon, M.A.; Chandrashekar, J.; Guo, W.; Tränkner, D.; Ryba, N.J.; Zuker, C.S. The cells and logic for mammalian sour taste detection. Nature 2006, 442, 934-938. [CrossRef] [PubMed]

13. Kataoka, S.; Yang, R.; Ishimaru, Y.; Matsunami, H.; Sévigny, J.; Kinnamon, J.C.; Finger, T.E. The candidate sour taste receptor, PKD2L1, is expressed by type III taste cells in the mouse. Chem. Senses 2008, 33, 243-254. [CrossRef] [PubMed]

14. Horio, N.; Yoshida, R.; Yasumatsu, K.; Yanagawa, Y.; Ishimaru, Y.; Matsunami, H.; Ninomiya, Y. Sour taste responses in mice lacking PKD channels. PLoS ONE 2011, 6, e20007. [CrossRef] [PubMed]

15. Shankaran, H.; Wiley, H.S.; Resat, H. Receptor downregulation and desensitization enhance the information processing ability of signalling receptors. BMC Syst. Biol. 2007, 1, 48. [CrossRef] [PubMed]

16. Knutson, V.P.; Ronnett, G.V.; Lane, M.D. Rapid, reversible internalization of cell surface insulin receptors. Correlation with insulin-induced down-regulation. J. Biol. Chem. 1983, 258, 12139-12142. [PubMed]

17. Gavin, J.R.; Roth, J.; Neville, D.M.; De Meyts, P.; Buell, D.N. Insulin-dependent regulation of insulin receptor concentrations: A direct demonstration in cell culture. Proc. Natl. Acad. Sci. USA 1974, 71, 84-88. [CrossRef] [PubMed]

18. Kahn, C.R.; Neville, D.M.; Roth, J. Insulin-receptor interaction in the obese-hyperglycemic mouse a model of insulin resistance. J. Biol. Chem. 1973, 248, 244-250. [PubMed]

19. Kahn, C.R.; Neville, D.M.; Gorden, P.; Freychet, P.; Roth, J. Insulin receptor defect in insulin resistance: Studies in the obese-hyperglycemic mouse. Biochem. Biophys. Res. Commun. 1972, 48, 135-142. [CrossRef]

20. Soll, A.H.; Kahn, C.R.; Neville, D.M. Insulin binding to liver plasm membranes in the obese hyperglycemic (ob/ob) mouse. Demonstration of a decreased number of functionally normal receptors. J. Biol. Chem. 1975, 250, 4702-4707. [PubMed]

21. Petersen, B.; Beckner, S.; Blecher, M. Hormone receptors 7. Characteristics of insulin receptors in a new line of cloned neonatal rat hepatocytes. Biochim. Biophys. Acta (BBA) Gen. Subj. 1978, 542, 470-485. [CrossRef]

22. Bar, R.S.; Gorden, P.H.; Roth, J.E.; Kahn, C.R.; De Meyts, P.I. Fluctuations in the affinity and concentration of insulin receptors on circulating monocytes of obese patients: Effects of starvation, refeeding, and dieting. J. Clin. Investig. 1976, 58, 1123-1135. [CrossRef] [PubMed]

23. Cidlowski, N.B.; Cidlowski, J.A. Regulation of Glucocorticoid Receptors by Glucocorticoids in Cultured HeLa S3 Cells. Endocrinology 1981, 109, 1975-1982. [CrossRef] [PubMed]

24. Schlechte, J.A.; Ginsberg, B.H.; Sherman, B.M. Regulation of the glucocorticoid receptor in human lymphocytes. J. Steroid Biochem. 1982, 16, 69-74. [CrossRef]

25. Maffei, M.; Halaas, J.; Ravussin, E.; Pratley, R.E.; Lee, G.H.; Zhang, Y.; Kern, P.A. Leptin levels in human and rodent: Measurement of plasma leptin and ob RNA in obese and weight-reduced subjects. Nat. Med. 1995, 1, 1155-1161. [CrossRef] [PubMed]

26. Martin, R.L.; Perez, E.; He, Y.J.; Dawson, R.; Millard, W.J. Leptin resistance is associated with hypothalamic leptin receptor mRNA and protein downregulation. Metabolism 2000, 49, 1479-1484. [CrossRef] [PubMed]

27. Kebabian, J.W.; Zatz, M.; Romero, J.A.; Axelrod, J. Rapid changes in rat pineal beta-adrenergic receptor: Alterations in 1-(3H) alprenolol binding and adenylate cyclase. Proc. Natl. Acad. Sci. USA 1975, 72, 3735-3739. [CrossRef] [PubMed]

28. Lefkowitz, R.J.; Mullikin, D.; Wood, C.L.; Gore, T.B.; Mukherjee, C.H. Regulation of prostaglandin receptors by prostaglandins and guanine nucleotides in frog erythrocytes. J. Biol. Chem. 1977, 252, 5295-5303. [PubMed]

29. Ren, X.; Zhou, L.; Terwilliger, R.; Newton, S.; De Araujo, I.E. Sweet taste signaling functions as a hypothalamic glucose sensor. Front. Integr. Neurosci. 2009, 3, 12. [CrossRef] [PubMed]

30. Medina, A.; Nakagawa, Y.; Ma, J.; Li, L.; Hamano, K.; Akimoto, T.; Kojima, I. Expression of the glucose-sensing receptor TAS1R3 in pancreatic islet: Changes in the expression levels in various nutritional and metabolic states. Endocr. J. 2014, 61, 797-805. [CrossRef] [PubMed] 
31. Smith, K.R.; Hussain, T.; Azari, E.K.; Steiner, J.L.; Ayala, J.E.; Pratley, R.E.; Kyriazis, G.A. Disruption of the sugar-sensing receptor TAS1R2 attenuates metabolic derangements associated with diet-induced obesity. Am. J. Physiol. Endocrinol. Metab. 2016, 310, E688-E698. [CrossRef] [PubMed]

32. Perea-Martinez, I.; Nagai, T.; Chaudhari, N. Functional Cell Types in Taste Buds Have Distinct Longevities. PLoS ONE 2013, 8, e53399. [CrossRef] [PubMed]

33. Bertino, M.; Beauchamp, G.K.; Engelman, K. Long-term reduction in dietary sodium alters the taste of salt. Am. J. Clin. Nutr. 1982, 36, 1134-1144. [CrossRef] [PubMed]

34. Bertino, M.; Beauchamp, G.K.; Engelman, K. Increasing dietary salt alters salt taste preference. Physiol. Behav. 1986, 38, 203-213. [CrossRef]

35. Pangborn, R.M.; Pecore, S.D. Taste perception of sodium chloride in relation to dietary intake of salt. Am. J. Clin. Nutr. 1982, 35, 510-520. [CrossRef] [PubMed]

36. Wise, P.M.; Nattress, L.; Flammer, L.J.; Beauchamp, G.K. Reduced dietary intake of simple sugars alters perceived sweet taste intensity but not perceived pleasantness. Am. J. Clin. Nutr. 2016, 103, 50-60. [CrossRef] [PubMed]

37. Noel, C.A.; Sugrue, M.; Dando, R. Participants with pharmacologically impaired taste function seek out more intense, higher calorie stimuli. Appetite 2017, 117, 74-81. [CrossRef] [PubMed]

38. Stewart, J.E.; Keast, R.S.J. Recent fat intake modulates fat taste sensitivity in lean and overweight subjects. Int. J. Obes. 2012, 36, 834-842. [CrossRef] [PubMed]

39. Noel, C.A.; Finlayson, G.; Dando, R. Prolonged Exposure to Monosodium Glutamate in Healthy Young Adults Decreases Perceived Umami Taste and Diminishes Appetite for Savory Foods. J. Nutr. 2018, 148, 980-988. [CrossRef] [PubMed]

40. Tepper, B.J.; White, E.A.; Koelliker, Y.; Lanzara, C.; d'Adamo, P.; Gasparini, P. Genetic variation in taste sensitivity to 6-n-propylthiouracil and its relationship to taste perception and food selection. Ann. N. Y. Acad. Sci. 2009, 1170, 126-139. [CrossRef] [PubMed]

41. Feeney, E.; O’Brien, S.; Scannell, A.; Markey, A.; Gibney, E.R. Genetic variation in taste perception: Does it have a role in healthy eating? Proc. Nutr. Soc. 2011, 70, 135-143. [CrossRef] [PubMed]

42. Martin, C.; Passilly-Degrace, P.; Gaillard, D.; Merlin, J.-F.; Chevrot, M.; Besnard, P. The Lipid-Sensor Candidates CD36 and GPR120 Are Differentially Regulated by Dietary Lipids in Mouse Taste Buds: Impact on Spontaneous Fat Preference. PLoS ONE 2011, 6, e24014. [CrossRef] [PubMed]

43. Zhang, X.J.; Zhou, L.H.; Ban, X.; Liu, D.X.; Jiang, W.; Liu, X.M. Decreased expression of CD36 in circumvallate taste buds of high-fat diet induced obese rats. Acta Histochem. 2011, 113, 663-667. [CrossRef] [PubMed]

44. Maliphol, A.B.; Garth, D.J.; Medler, K.F. Diet-Induced Obesity Reduces the Responsiveness of the Peripheral Taste Receptor Cells. PLoS ONE 2013, 8, e79403. [CrossRef] [PubMed]

45. Drewnowski, A.; Brunzell, J.D.; Sande, K.; Iverius, P.H.; Greenwood, M.R. Sweet tooth reconsidered: Taste responsiveness in human obesity. Physiol. Behav. 1985, 35, 617-622. [CrossRef]

46. Shi, D.; Nikodijević, O.; Jacobson, K.A.; Daly, J.W. Chronic Caffeine Alters the Density of Adenosine, Adrenergic, Cholinergic, GABA, and Serotonin Receptors and Calcium Channels in Mouse Brain. Cell. Mol. Neurobiol. 1993, 13, 247-261. [CrossRef] [PubMed]

47. Yoshida, R.; Ninomiya, Y. Taste information derived from TAS1R-expressing taste cells in mice. Biochem. J. 2016, 473, 525-536. [CrossRef] [PubMed]

48. Oka, Y.; Butnaru, M.; von Buchholtz, L.; Ryba, N.J.; Zuker, C.S. High salt recruits aversive taste pathways. Nature 2013, 494, 472. [CrossRef] [PubMed]

49. Stein, L.J.; Cowart, B.J.; Beauchamp, G.K. The Development of Salty Taste Acceptance Is Related to Dietary Experience in Human Infants: A Prospective Study. Am. J. Clin. Nutr. 2012, 95, 123-129. [CrossRef] [PubMed]

50. Grassin-Delyle, S.; Abrial, C.; Fayad-Kobeissi, S.; Brollo, M.; Faisy, C.; Alvarez, J.C.; Devillier, P. The expression and relaxant effect of bitter taste receptors in human bronchi. Respir. Res. 2013, 14, 134. [CrossRef] [PubMed]

51. Chandrashekar, J.; Mueller, K.L.; Hoon, M.A.; Adler, E.; Feng, L.; Guo, W.; Ryba, N.J. T2Rs function as bitter taste receptors. Cell 2000, 100, 703-711. [CrossRef]

52. Lipchock, S.V.; Mennella, J.A.; Spielman, A.I.; Reed, D.R. Human bitter perception correlates with bitter receptor messenger RNA expression in taste cells. Am. J. Clin. Nutr. 2013, 98, 1136-1143. [CrossRef] [PubMed] 
53. Lipchock, S.V.; Spielman, A.I.; Mennella, J.A.; Mansfield, C.J.; Hwang, L.D.; Douglas, J.E.; Reed, D.R. Caffeine bitterness is related to daily caffeine intake and bitter receptor mRNA abundance in human taste tissue. Perception 2017, 46, 245-256. [CrossRef] [PubMed]

54. Shigemura, N.; Shirosaki, S.; Sanematsu, K.; Yoshida, R.; Ninomiya, Y. Genetic and molecular basis of individual differences in human umami taste perception. PLoS ONE 2009, 4, e6717. [CrossRef] [PubMed]

55. Beeler, J.A.; McCutcheon, J.E.; Cao, Z.F.; Murakami, M.; Alexander, E.; Roitman, M.F.; Zhuang, X. Taste uncoupled from nutrition fails to sustain the reinforcing properties of food. Eur. J. Neurosci. 2012, 36, 2533-2546. [CrossRef] [PubMed]

56. Wu, A.; Dvoryanchikov, G.; Pereira, E.; Chaudhari, N.; Roper, S.D. Breadth of tuning in taste afferent neurons varies with stimulus strength. Nat. Commun. 2015, 6, 8171. [CrossRef] [PubMed]

57. Boughter, J.D.; Raghow, S.; Nelson, T.M.; Munger, S.D. Inbred mouse strains C57BL/6J and DBA/2J vary in sensitivity to a subset of bitter stimuli. BMC Genet. 2005, 6, 36. [CrossRef] [PubMed]

58. Dando, R.; Roper, S.D. Acetylcholine is released from taste cells, enhancing taste signalling. J. Physiol. 2012, 590, 3009-3017. [CrossRef] [PubMed]

(C) 2018 by the authors. Licensee MDPI, Basel, Switzerland. This article is an open access article distributed under the terms and conditions of the Creative Commons Attribution (CC BY) license (http:/ / creativecommons.org/licenses/by/4.0/). 